NBER WORKING PAPER SERIES

INTERNATIONAL BALANCE OF PAYMENTS

FINANCING AND ADJUSTMENT

Willem H. Buiter

Jonathan Eaton

Working Paper No. 1120

NATIONAL BUREAU OF ECONOMIC RESEARCH

1050 Massachusetts Avenue

Cambridge MA 02138

May 1983

This paper is forthcoming in the book International Money, Credit, and the SDR, edited by George M. von Furstenberg (International Monetary Fund, Washington, D.C., 1983). The research reported here is part of the NBER's research program in International Studies. Any opinions expressed are those of the authors and not those of the National Bureau of Economic Research. 


\title{
International Balance of Payments \\ Financing and Adjustment
}

\begin{abstract}
This paper explores some 1mplications of the use of national currencies as interrational reserves. First, a closed economy overlapplng-generations model is developed to derive time-consistent tax and inflation policies for a government that is financing a given stream. of expenditures. Second, the effects of allowing a government to hold a foreign currency as a reserve asset and to have its currency held as a reserve asset abroad are considered. The use of national. currencies as currencies of denomination for international lending creates an incentive for the governments whose currencies are used to alter their inflation rates to extract resources from the rest of the world. When reserves are constrained to be ronnegative the use of national currencies as international reserves raises the Inflation rate in reserve issulng countries but does not effect the Infiation rate in reserve holders. The opposite result arises when louns are denoudnated in the borrowers' currenctes.

Willem H. Buiter Department of Econonf.cs London School of Economics Houghton Street London WC2A $2 A E$ ENGLAND

$011 / 44 / 272-24161, \times 67$

\author{
Jonathan Eaton \\ Economic Growth Center \\ Yale University \\ P.0. Box 1987, Yale Station \\ 27 Hillhouse Avenue \\ New Haven, Conn, 06520
}

$203 / 436-8414$
\end{abstract}


INTERNATIONAL BALANCE OF PAYMENTS FiNANCING AND ADJUSTMENT

Willem H. Buiter

London School of Economics

Jonathan Eaton

Yale University

With the decline in the role of gold in the international economy the primary method that countries have used to finance payments imbalances has been borrowing and lending denominated in terms of national currencles. In the last century sterling was the primary reserve currency while in this ceutury it has been the U.S. dollar. Recently the currencles of a number of additional countries have emerged as international stores of values. These currencies have also served as the primary currencles of denomination of international loans. The Introduction of Special Drawing Rights (SDR's) constitutes an attempt to replace national moneys with an international money for use as an international reserve. Its adoption thus far has been only partial, however, and its value remains tied to that of national currencles. In the absence of a credible cammitment to a commodity exchange standard such as the gold exchange standard, the value of assets and liabilities denominated in national currencles has been subject to the political control of the governments and central banks issuing those currencles. The use of these currencles to finance payments imbalances w111 depend upon the expectations held by international transactors about the strength of these institutions' commitment to maintain the real values of their currencles.

Nevertheless, a currency's introduction into use as an International store of value changes the context in which the issuers of currencies act. First, the process whereby national currencies are distributed throughout the world economy requires an adjustment via payments 1 mbalances that may . have severe economic consequences for reserve issuers and holders alike. Second the presence of large currency balances held outside the country of 1ssue and of loans abroad denominated in local currency has sertous. 
Implications for the effect of central bank policy on national welfare. As a consequence, one might anticipate that being thrust into the role of a reserve issuer or International lender may significantly change the Issuing country's monetary policy.

It is widely recognized that the use of a currency as an international reserve and currency of denomination of international assets and liabllities requires trust in the issuer's willingness and abllity to maintain the real value of tts currency. Triffin's (1961) discussion of the dollar problem emphasized that the U.S. dollar's widespread use as a reserve currency could, by itself, undermine bellef in its long-run stability. The incentives facing a reserve issuer to undermine the value of 1 ts currency by inflation have been discussed by Mundel1 (1971) and Calvo (1978).

The use of national moneys as international reserves raises a number of questions: (1) What characteristics of a country make it Iikely to emerge as a reserve issuer? (11) How does becoming a reserve issuer affect the inflation rate that is optimal from a national perspective? (1i1) If, in fact, the rate of return on a currency is likely to fall if it is adopted as an international reserve, why are other countries' central banks willing to hold this currency as a reserve if they percelve this effect? and (Iv) What are the costs and benefits of becoming a reserve issuer and a reserve holder?

Our purpose in this paper is to develop a model. of the interaction of national monetary polfcy and international regerves to answer these questions. The issue is considered from the perspective of both 
reserve 1ssuers and reserve holders.

To understand how the use of national moneys as international reserves affects the conduct of monetary policy, one needs to specify the objectives of the government and the technology and preferences of the private sector. To generate a demand for currency at the national level, the exact consumption loan model of Samuelson (1958) is adopted. While this framework is very simple and highly stylized, it does generate a demand for money based directly on an underlying technology and individual preferences. Precise welfare comparisons across regimes are therefore possible, ${ }^{1}$

We assume that the government of each country must meet an exogenous level of government spending each period. This expenditure may be financed via a nondistortionary tax imposed on the current younger generation or by monetary issue. The government's objective is to maximize a welghted average of the lifetime utilities of all generations of its citizens.

Section I of the paper presents a closed-economy version of the model. The tax rate and inflation rate that obtain in each period reflect the government's welghting of the younger and older generations currently alive, The greater the welght placed on the older generation, the lower the inflation rate, and conversely. Only when equal weight is placed on the representative member of each generation alive does the steady-state rate of return on money balances equal the growth rate, achieving the golden rule. Otherwise, the lifetime utility of the representative citizen in the steady state is below the maximum possible level. When, in fact, this is 
due to a rate of return on currency below the growth rate (when the government places greater weight on the utility of the younger generation), the outcome is not Pareto efficient. The problem arises because the government In any given period cannot credibly commit itself or its successor in the next period to avoid inflating the currency at a faster rate, thereby reducing the rate of return on savings to the current younger generation. It constitutes an example of the problem of the time inconsistency of optimal policy discussed by Kydland and Prescott (1977).

Section II introduces foreign reserves into the model. It incorporates both domestic holdings by the government of forelgn currency and foreign holdings of domestic currency. We assume that reserve holders take current and future returns on foreign currencies as given, anticipating them correctly, and that reserve issuers take current and future holdings by foreigners of their currency as given, anticipating these correctiy as well. We show that holding a foreign currency as a reserve does not affect the steady state inflation rate of the reserve holding country. The demand for reserves depends not only upon the government's weighting of the two generations currently alive but upon its welghting of future generations. When the government assigns future generations weights that decline geometrically into the future, then foreign reserves are demanded perfectly elastically at the rate of return on domestic currency. When the government acts only in the interests of generations currently alive, the demand for reserves is also infinitely elastic, but at a rate of return that is higher than that on domestic currency. 
The rate of inflation in the reserve issuer is, however, affected by changes in foreign holdings of domestic reserves. The effect of an Increasein foreign holdings on impact is ambiguous, but in the new steady state, in which more reserves are held abroad, the rate of inflation in the issuing country is necessarily higher.

Section III considers global equilibrium in a world in which there are two types of countries, one characterized by a low inflation rate under financial autarky and another by a high inflation rate under financial autarky. We distinguish two cases, one in which gross International lending is always denominated in the currency of the lender, in which case reserves are constrained to be nonnegative, and the opposite case in which borrowing is always denominated in the currency of the borrower. The two cases generate quite different equilibria. Our model does not predict which type of equilibrium will emerge, or if it will be an intermediate one. This paper suggests, however, that a theory of default combined with an assumption of convertibility may be incorporated into the model to endogentze this deciston. ${ }^{2}$ We show that when loans are denominated in the currency of the borrower countries with low rates of inflation under financial autarky become borrowers, while countries with high inflation rates become lenders. Becoming a borrower in its own currency raises a country's steady-state inflation rate but has no effect on the steady-state inflation rate of the lender. Moving from financlal autarky to trade in reserves thus raises the average world inflation rate. The effect during the 
transition from one steady state to the other may be quite different, however, with the reserve issuer experiencing a lower inflation rate along the way. The opposite results with respect to inflation arise when loans are denominated in the lender's currency. In this case, the high-inflation countries lend to low-inflation ones in the former group's currencies. These loans then provide an incentive for lenders to lower their inflation rates but have no effect on inflation in the second group. The average world inflation rate is consequently lower in the long run.

Our model allows one to compute the welfare effects of trade in reserves. We find that in the steady state, the utility of the representative generation is higher in lender countries but can be lower in borrower countries. The effects on generations alive during the transition may be quite different, however. The results thus suggest a justification for attempts by some governments to prevent their currencies from becoming reserve currencies.

Section IV discusses some possible extensions of our analys is that we believe would be especially worthwhile. Each of the issues raised here can potentially be analyzed in the framework we have developed, but they lie beyond the scope of a single paper. Section V provides a summary of the major results. 


\section{The Closed Economy Mode1}

We illustrate our points in a very simple model. Our point of departure is the Samuelson (1958) exact consumption-loan model. Individuals live two periods, earning income only in the first period and saving a fraction of that income in order to consume in the second period. Individuals who enter the labor force in perlod $t$ earn, before tax, an exogenously given amount $y_{t}$ in the first period of their lives, a fraction $\tau_{t}$ of which is taxed by the government. Domestic government debt, which is assumed to be monetary, is the only asset available to individuals as a store of value. Output is nonstorable.

We assume that the utility function of a representative individual entering the labor force in period $t$ is given by

$$
U_{t}=\ln \quad C_{t}^{y}+B \ln C_{t+1}^{0} \quad 0 \leq B
$$

where $c_{t}^{y}$ denotes consumption in the first period of 11 fe, $t$, when the Individual is young, and $c_{t+1}^{0}$ consumption when the individual is old, period $t+1$. While the Bernoulli assumption is special it provides a number of restrictions that simplify the analysis substantially. We will discuss the implication of relaxing some of these assumptions later on.

Let $P_{t}$ denote the price level in period $t$ and let $m_{t}^{d}$ denote the real savings, and hence real money holdings at the end of period $t$ of an individual born in period $t$. In period $t$, then, the individual chooses $c_{t}^{y}$ and $m_{t}^{d}$ to maximize $U_{t}$ subject to the budget constraints 


$$
\begin{array}{r}
y\left(1-\tau_{t}\right)-c_{t}^{y}-m_{t}^{d} \geq 0 \\
c_{t+1}^{0} \leq{ }_{t+1} m_{t}^{d}
\end{array}
$$

Here we define the inverse of one plus the inflation rate from period $t$ to period $t+1$ as

$$
\pi_{t+1} \equiv \frac{P_{t}}{P_{t+1}}
$$

which equals one plus the rate of return on real money balances.

$$
\begin{aligned}
& \text { First-order conditions for a maximum imply } \\
& c_{t}^{y}=\frac{1}{1+\beta}\left(1-\tau_{t}\right) y_{t} \\
& m_{t}^{d}=\frac{\beta}{1+\beta}\left(1-\tau_{t}\right) y_{t} \\
& c_{t}^{0}=\pi_{t+1} \frac{\beta}{1+\beta}\left(1-\tau_{t}\right) y_{t}
\end{aligned}
$$

The government is required to meet a real expenditure path $G_{t}$. It collects, in period $t$, a real amount $\tau_{t} y_{t} L_{t}$ in tax revenue where $L_{t}$ equals the number of young individuals in period $t$. The deficit is financed by monetary 18sue. The government budget constraint is therefore

$$
G_{t}-\tau_{t} y_{t} L_{t}=\frac{M_{t}^{d}-M_{t-1}^{d}}{P_{t}}
$$

where $M_{t}^{d}$ denotes is the nominal money supply at the end of period $t$. Using the definition

$$
m_{t}^{d} \equiv \frac{M_{t}^{d}}{P_{t}^{L_{t}}}
$$


and dividing equation (4) by $L_{t}$ ylelds, in per worker terms,

$$
g_{t}-\tau^{\tau} t_{t}^{y_{t}}=m_{t}^{d}-m_{t-1}^{d} \pi_{t}\left(1+n_{t}\right)^{-1}
$$

where $n_{t}$ denotes the growth in the labor force from period $t-1$ to period $t$ and $g_{t}$ denotes government spending per worker. The government's objective in each period $t$ is to choose a tax rate $\tau_{t}$ to maximize a weighted sum of the utilities of all generations subject to equation (4) or ( $\left.4^{*}\right)$. Thus, in each period $t$, the government's objective function $w_{t}$ is given by

$$
w_{t} \equiv \sum_{i=-\infty}^{\infty} w_{t+i} U_{t+1}
$$

In choosing $\tau_{t}$ in period $t$, the government takes all past $\tau_{1}$ as given and assumes that it or its successor will behave equivalently in the future. Covernments are therefore assumed to behave in a time-consistent fashion and to anticipate this behavior correctly. Solving the government budget constraint ( $4^{\prime}$ ) incorporating optimal private savings behavior characterized by equation ( $\left.3^{\prime}\right)$ yields, as an expression for the rate of return on currency In period $t$,

$$
\pi_{t}=\frac{\left[\left(\frac{B+\tau_{t}}{1+\beta}\right) y_{t}-g_{t}\right]\left(1+n_{t}\right)}{M_{t-1}^{d}}
$$

Substituting equations (6) and (3) Into equation (1) yields, as an expression for the utillty of a representative member of the generation born in period $t$,

$$
\begin{aligned}
& U_{t}=k+(1+\beta) \ln y_{t}+(1+\beta) \ln \left(1-\tau_{t}\right)+\beta \ln \pi_{t+1} \\
& k \equiv B \ln \beta-(1+\beta) \ln (1+\beta)
\end{aligned}
$$


where $\pi_{t}$ is as defined in (6). Substituting equations ( $\left.1^{\prime}\right)$ and (6) into the government's objective function (5) and maximizing with respect to $\tau_{t}$ yields, from the first-order condition for a maximum,

$$
\tau_{t}=\frac{\beta\left(1-\delta_{t}\right) y_{t}+\delta_{t}(1+\beta) g_{t}}{\left(\beta+\delta_{t}\right) y_{t}} ; \delta_{t} \equiv \frac{w_{t}}{w_{t-1}}
$$

whlch, from equation (6), implies

$$
\pi_{t}=\frac{\beta\left(y_{t}-g_{t}\right)\left(1+n_{t}\right)}{\left(\beta+\delta_{t}\right) m_{t-1}^{d}}
$$

Note from expression (7) that when $\delta=1$ (generations born at $t$ and at $t+1$ enter the government's objective function with equal weight) then:

$$
\tau_{t}=g_{t} / y_{t}
$$

-that is, all. government spending is tax financed. When $\delta_{t}>1_{i}$ so that greater weight is attached to the utility of the younger generation, then $\tau_{t}<g_{t} / y_{t}$, so that some government spending is financed by monetary issue. Conversely, when $\delta_{t}<1$, so that greater weight is attached to the older generation, $\tau_{t}>g_{t} / y_{t}-$ that $1 s$, taxes exceed expenditure--so that debt 18 retired. If the government objective function is a Benthamite one, so that the weight of each living generation is proportional to the number of 1 ts members, then $\delta_{t}=\left(1+n_{t}\right)$, in which case, if population growth Is positive, there is an ongoing deficit. 
From expression (8), observe that the inflation rate in period $t$ 1s higher: (1) the greater government spending is relative to income, (11) the higher real money balances are at the end of the previous period, and (iii) the lower the population growth rate.

From equation ( 3 ),

$$
m_{t-1}^{d}=\frac{B}{1+\beta}\left(1-\tau_{t-1}\right) y_{t-1}
$$

which, if optimal tax policy was pursued in period $t-1$

$$
\pi_{t}=\frac{\left(1+n_{t}\right)}{\delta} \quad \frac{y_{t}-g_{t}}{y_{t-1}-g_{t-1}}
$$

When the two living generations recelve equal weight $(\delta=1)$ and income less government spending is equal across periods, then the rate of return on money balances equals the population growth rate: the economy is following the golden rule. If $\delta>1$ or if income less government spending 1s decreasing, then the rate of return on money balances is less than the population growth rate, and conversely. In the case of the Benthamite utlity function and constant population growth, the rate of return on money is zero. 
II. An Open Economy Model with Reserves

Consider now a situation in which the government of the country being considered (1) has available to it a foreign money which can be held as a reserve currency or ( $(1)$ finds that some of its money is held abroad as a reserve currency. Denote foreign holdings of domestic money denominated in domestic currency in period $t$ as $\mathrm{M}_{t}$ and domestic holdings of forelgn currency denominated in forelgn currency in period $t$ as $M_{t}^{\star} d$. Let $P_{t}^{*}$ denote the price level in terms of foreign currency in period $t$ and $E_{t}$ the domestic currency price of one unit of foreign currency. It is assumed that purchasing power parity obtains, so that .

$$
E_{t}=P_{t} / P_{t}^{*}
$$

Allowing for these government holdings of assets modifies the government budget constraint, equation (4), so that it becomes

$$
G_{t}-T_{t} Y_{t} L_{t}=\frac{M_{t}^{d}-M_{t-1}^{d}}{P_{t}}+\frac{M_{t}^{f}-M_{t-1}^{f}}{P_{t}}-\frac{E_{t}\left(M_{t}^{* d}-M_{t-1}^{* d}\right)}{P_{t}}
$$

It is assumed that no international transfers take place.

Defining real domestic currency holdings abroad per domestic worker as

$$
m_{t}^{f} \equiv \frac{M_{t}^{f}}{P_{t}^{L} L_{t}}
$$

and real foreign currency holdings by the domestic government per foreign worker (where $L_{t}^{*}$ denotes the number of forelgn workers in period $t$ ) as

$$
m_{t}^{* d} \equiv \frac{M_{t}^{* 1}}{P_{t}^{*} L_{t}^{*}},
$$


the real rate of return on forelgn currency as

$$
\pi_{t}^{*} \equiv \frac{P_{t-1}^{*}}{P_{t}^{*}},
$$

and the ratio of forelgn workers to domestic workers in period $t$ as

$$
\lambda_{t} \equiv \frac{L_{t}^{*}}{L_{t}}
$$

the government budget constraint may be written

$$
\begin{aligned}
g_{t}=\tau_{t}{ }^{y}=m_{t}^{d} & -m_{t-1}^{d} \pi_{t}\left(1+n_{t}\right)^{-1}+m_{t}^{f}-m_{t-1}^{f} \pi_{t}\left(1+n_{t}\right)^{-1} \\
& -\lambda_{t}\left[m_{t}^{*} d-m_{t-1}^{* d} \pi_{t}^{*}\left(1+n_{t}^{*}\right)^{-1}\right]
\end{aligned}
$$

where $n_{t}^{*}$ denotes the growth in the number of forelgn workers between period $t-1$ and period $t$.

The Behavior of a Reserve Holder

Consider first the situation of a country whose currency is not held abroad, but which contemplates holding a foreign currency as a reserve. We assume that this country treats the rate of return on the reserve currency, $\pi_{1}^{*}$, as exogenous to 1 ts own behavior for all 1 . 
One reason is that this country may be one of a large number of small countries that hold this reserve currency, and its contribution to total demand is negligible. We assume that this country anticlpates perfectly the actual rate of return on forelgn currency.

Setting $m_{i}^{f}=0$ for all 1 in equation (17), this country chooses In each period $t$ a tax rate $\tau_{t}$ and an amount of reserves $\lambda_{t} m_{t}{ }_{d}$ to maximfze its objective function $W_{t}$, which, it is assumed, continues to be given by equation (5), with $\delta_{t}=w_{t} / w_{t-1}=\delta$

Defining

$\hat{g}_{t}=g_{t}+\lambda_{t}\left[m_{t}^{* d}-\pi_{t}^{*}\left(1+n_{t}\right)^{-1} m_{t-1}^{* d}\right]$

the optimal tax rate $\tau_{t}$ is given by

$$
\tau_{t}=\frac{\delta(1+\beta) \hat{g}_{t}+B(1-\delta) y_{t}}{(\delta+\beta) y_{t}}
$$

The rate of inflation is consequently

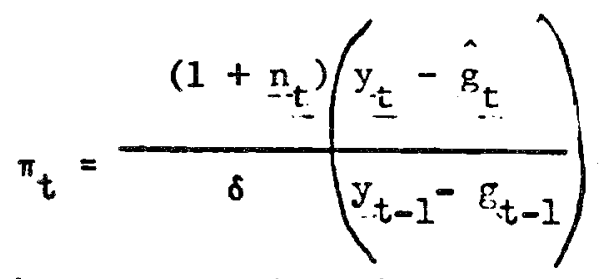

Substituting these expressions into $W_{t}$ yields

$$
\left.w_{t}=\sum_{i=-\infty}^{\infty} w_{1}+\ln \left(y_{1}-\hat{g}_{i}\right)+B \ln \left(y_{j}+1-\hat{g}_{i-1}\right)\right]
$$

where

$$
k \pm \equiv-(1+\beta) \ln (1+\beta)+\ln \delta+\ln \beta+\ln (1+n+1)
$$


Differentiating this expression with respect to $m_{t}^{{ }^{d}}$ yields, as a firstorder condition for a maximum,

$$
\begin{aligned}
& \quad \frac{-\lambda_{t}\left(w_{t}+\beta w_{t-1}\right)}{\tilde{y}_{t}-\lambda_{t}\left(m_{t}^{* d}-m_{t-1}^{* d} x_{t}\right)}+\frac{\lambda_{t+1}\left(w_{t+1}+\beta w_{t}\right) x_{t+1}}{\tilde{y}_{t+1}-\lambda_{t+1}\left(m_{t+1}^{* d}-m_{t}^{* d} x_{t+1}\right)} \\
& +\quad \sum_{t+1}^{\infty} \frac{d w_{t}^{*}}{d m_{i}^{* d}} \frac{d_{1}^{* d}}{d m^{* d}}=0
\end{aligned}
$$

where

$$
\begin{aligned}
& x_{t} \equiv \pi_{t}^{*}\left(1+n_{t}\right)^{-1} \\
& \dot{y}_{t} \equiv y_{t}-g_{t}
\end{aligned}
$$

Note that since $m_{t}^{* d}$ depends upon $m_{t-1}^{\star d}$, in general future values of $m^{{ }^{*} d}$ will be affected by the current reserve holding decision. The best cholce from the current perspective must incorporate the effect of that choice on the country's own future policy response.

This paper will now focus on two special cases

$$
\text { Case 1. } w_{i}=w_{t-1} \rho^{i} ; \quad i \neq t, \ldots, \infty \quad \rho<1
$$

In this case one may write

$$
w_{t}\left(m_{t-1}^{*}\right)=\left(w_{t-1} \beta k_{t-1}+w_{t} k_{t}\right) \ln \left(y_{t}-g_{t}\right)+0 \cdot w_{t+1}\left(m_{t}^{* d}\right)
$$


If optimal policy is pursued in each period $1>t$ then

$$
\frac{d W_{1}}{d m_{1}^{{ }^{d}}}=0 \quad 1 \geq t+1
$$

and expression (23) reduces to

$$
-\frac{\left(w_{t}+B w_{t-1}\right)}{\tilde{y}_{t}-\lambda_{t}\left(m_{t}^{* d}-m_{t-1}^{*_{d}} x_{t}\right)}+\frac{\left(w_{t+1}+B w_{t}\right) x_{t+1}}{y_{t+1}-\lambda \lambda_{t+1}\left(m_{t+1}^{* d}-m_{t}^{{ }_{d}} x_{t+1}\right)}=0
$$

In the steady state $\lambda_{t}=\lambda_{t+1}=\lambda, \tilde{y}_{t+1}=\tilde{y}_{t}=y, \cdot x_{t+1}=x$,

$m_{t-1}^{* d}=m_{t}^{* d}=m_{t+1}^{*_{d}}=m^{* d}$ Therefore expression $\left(23^{\prime}\right)$ can be obtained only if

$$
\mathbf{x}=\rho^{-1}
$$

When $x$ exceeds $\rho^{-1}$ the demand for forelgn reserves is infinite in steady state while if $x_{t}$ is less than $\rho^{-1}$, demand equals negative Infinity. From Section $I$, the autarkic inflation rate 1 s $(1+n) / \delta$. Consequently, since $\delta=\rho$ in this case, the demand for foreign reserves in the steady state is bounded only when the rate of return on foreign reserves equals the return on domestic money. In other words, the demand for reserves is Infinftely elastic at the domestic inflation rate.

Case 2. $w_{1}=0$ i $\neq-1, t$

In this case, the current government only takes into account the welfare of generations currently alive. It assumes that future governments will act equivalently. The current government and future governments thus pursue different objectives. In particular, the current government must incorporate 
the effect of its current policies on the future government's treatment of the current younger generation.

To solve for optimal reserve demand, it is assumed that at each period $t$, foreign reserves are held according to the formula

$$
m_{t}^{* d}=a_{t}+b_{t} m_{t-1}^{* d}
$$

where $a_{t}$ and $b_{t}$ denote parameters to be determined.

Substituting expression (24) into the objective function for $m_{t+1}^{*_{d}}$ yields

$$
\begin{gathered}
w_{t}=\left(w_{t-1} \beta k_{t-1}+w_{t} k_{t}\right)+(\beta+\delta) \operatorname{n}\left[\tilde{y}_{t}-\lambda_{t}\left(m_{t}^{*_{d}}-m_{t-1}^{*_{d}} x_{t}\right)\right] \\
+\delta \beta \ln \left[\tilde{y}_{t+1}-\lambda_{t+1}\left(a_{t+1}+b_{t+1} m_{t}^{* d}{ }_{t+1} m_{t}^{* d}\right)\right]
\end{gathered}
$$

Differentiating this expression with respect to $m_{t}^{* d}$ yields as a first-order condition for a maximum:

$$
\frac{d W_{t}}{d m_{t}^{{ }^{*} d}}=\frac{-\lambda_{t}(\beta+\delta)}{\tilde{y}_{t}-\lambda_{t}\left(m_{t}^{{ }^{d}}-m_{t-1}^{k_{d}} x_{t}\right)}+\frac{\delta \beta \lambda_{t+1}\left(x_{t+1}-b_{t+1}\right)}{\tilde{y}_{t+1}-\lambda_{t+1}\left(a_{t+1}+b_{t+1} m_{t}^{{ }^{d} d}-x_{t+1} m_{t}^{* d}\right)}=0
$$

Solving equation (25) for $\mathrm{m}_{t}^{{ }_{\mathrm{d}}}$, one obtains

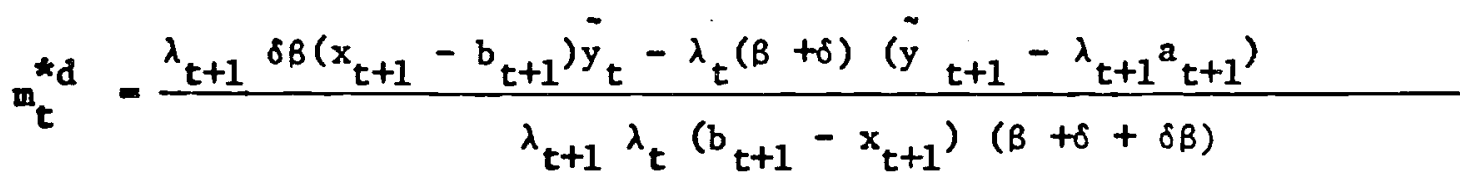

$$
\begin{aligned}
& +\frac{\delta \beta x_{t}}{\beta+\delta+\delta \beta} m_{t-1}^{*_{d}}
\end{aligned}
$$

Since an equivalent problem will be solved in period $t+1$ one may set 


$$
b_{t+1}=\frac{\delta \beta x_{t+1}}{\beta+\delta+\delta \beta}
$$

Substituting this expression into equation (26), it is found that

$$
a_{t}=\frac{\lambda_{t}(\beta+\delta+\delta \beta) \tilde{y}_{t+1}-\lambda_{t+1} \delta \beta x_{t+1} \tilde{y}_{t}}{\lambda_{t+1} \lambda_{t}(\beta+\delta+\delta \beta)}+a_{t+1}
$$

The steady state requires that

$$
\underset{\tilde{y}_{t+1}}{\tilde{y}_{t}}=\tilde{y}_{t}, x_{t+1}=x_{t}=x, \lambda t+1=\lambda_{t}=\lambda \text {, and } m_{t}^{* d}=m^{*}
$$

Inspection of equation (26) shows that the steady state is only compatible with a finite demand for reserves if

$$
x=\frac{B+\delta+\delta B}{\delta \beta}
$$

or

$$
x^{*}=\frac{(1+n)(\beta+\delta+\delta \beta)}{\delta \beta}
$$

If the rate of return on foreign reserves exceeds this level, demand will grow to infinity and conversely. Thus, in the long run the demand for foreign reserves is perfectly elastic at the rate of return $\frac{(1+n)(\beta+\delta+\beta \delta)}{\delta \beta}$.

This rate of return will exceed the return on domestic money, which remains $\frac{(1+n)}{\delta}$. Therefore a country in which the government maximizes the welfare of only generations currently alive will not hold reserves unless the. return strictly exceeds the rate of return on domestic currency. The reason is that an unborn generation, the younger generation in period $t+1$, will share the return from an investment in reserves in period $t$ with the younger generation in period $t$. The myopic government weights only the second gain in making its decision. Consequently, a higher rate of return is required for an investment in reserves to appear worthwhile. 
The Behavior of a Reserve Issuer

Consider now the behavior of a country which holds no foreign currencies, but which finds that forelgn countries hold its currency as a reserve. It is assumed that this country takes foreign holdings of its own currency, $\mathrm{m}_{i}^{f}$, as given in each period $i$. That is, when the government makes 1 ts taxation decision, other countries have made their past and contemporaneous reserve holding decisions. Because it raises a complicated, but very interesting, set of issues that lie beyond its scope, this paper Ignores the possibility of a reputation effect whereby reserye holders' expectations of future inflation are determined by past performance. Rather, reserve holders form expectation of future inflation by calculating the optimal behavior of the reserve issuer each period.

$$
\text { Setting } m_{i}^{*_{d}}=0 \text { for all } 1 \text { in equation (17), the expression for }
$$
Inflation, given $\tau_{t}$, becomes

$$
\pi_{t}=\frac{\left(1+n_{t}\right)\left[\left(\beta+\tau_{t}\right) y_{t}-(1+\beta) g_{t}+(1+\beta) m_{t}^{f}\right]}{\beta\left(1-\tau_{t-1}\right) y_{t-1}+(1+\beta) m_{t-1}^{f}}
$$

Since equations ( 3 ) and (3") continue to define consumption in each period, the utility of an individual entering the labor force in period $t$ is

$$
\begin{aligned}
& U_{t}=k_{t}^{\prime}+(1+\beta) \ln \left(1-\tau_{t}\right)-\beta \ln \left[\beta\left(1-\tau_{t}\right), y_{t}+(1+\beta) m_{t}^{f}\right] \\
&+\beta \ln \left[\left(\beta+\tau_{t+1}\right) y_{t+1}-(1+\beta) g_{t+1}+(1+\beta) m_{t+1}^{f}\right] \\
& k_{t}^{\prime} \equiv \ln \beta-(1+\beta) \ln (1+\beta)+\ln _{n}\left(1+n_{t}\right) .
\end{aligned}
$$

Continuing to assume a government objective function of the form of equation (5), the first-order condition for an optimal tax rate $\tau_{t}$ is given by 


$$
\begin{gathered}
\frac{d W_{t}}{d \tau_{t}}=w_{t-1} \frac{\beta y_{t}}{\Delta_{1 t}}-w_{t} \frac{(1+\beta)}{\left(1-\tau_{t}\right)}+w_{t} \frac{\beta^{2} y_{t}}{\Delta_{2 t}}=0 \\
\Delta_{1 t} \equiv\left(\beta+\tau_{t}\right) y_{t}-(1+\beta) g_{t}+(1+\beta) m_{t}^{f} \\
\Delta_{2 t} \equiv B\left(1-\tau_{t}\right) y_{t}+(1+\beta) m_{t}^{f}
\end{gathered}
$$

Note that the solution to equation (33) involves only contemporaneous vartables. The effect of an increase in contemporaneous money holdings,

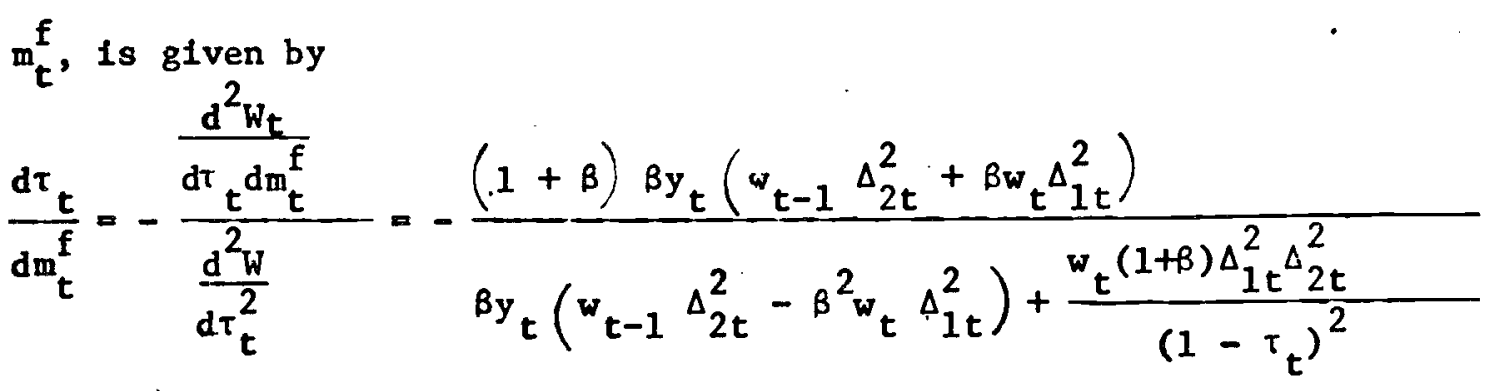

which is negative: the domestic tax rate falls as foreign holdings of the domestic currency rise.

Consider now the effect of an increase in foreign holdings of domestic currency on the rate of return on currency. Given current holdings, $m_{t}^{f}$, an increase in the previous period's holdings, $m_{t-1}^{f}$, lowers $\pi_{t}$. This result is evident from inspection of expression (31). The effect of an increase in $\mathrm{m}_{t}^{f}$, given $\mathrm{m}_{t-1}^{f}$, is 


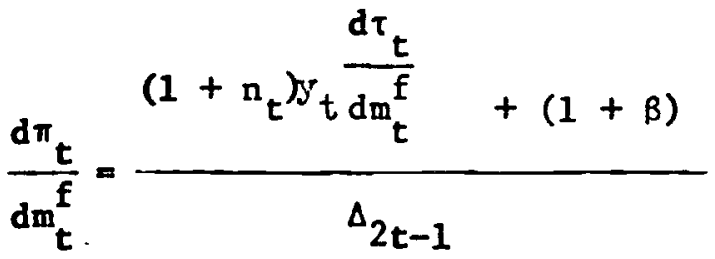

which, incorporating expression (34), has the same sign as

$$
(\beta+2)(\beta-1) \beta\left(1-\tau_{t}\right)^{2} y_{t}^{2}+2(1+\beta)^{2} \beta\left(1-\tau_{t}\right) y_{t} m_{t}^{f}+(1+\beta)^{3} m_{t}^{f}
$$

This expression is negative if $\mathrm{m}_{t}^{f}$ is small and $B$ is less than one. For large values of $\mathrm{m}_{t}$, it is positive. Therefore, an increase in foreign reserve holdings has an ambiguous effect on the inflation rate that period.

Consider an increase in foreign reserve holdings in period $t$ from a level of zero to some positive permanent level, $\mathrm{m}^{\mathrm{f}}$. The effect on $\pi_{t}$ on Impact is given by the sign of expression (36). The effect on $\pi_{i} i>t$, assuming constant values of $y_{t}$ and $g_{t}$, is given by $\frac{d \pi}{d m^{f}}=\frac{\left(1+n_{t}\right)(1+B)\left\{\left[B y+g+(1+B) m^{f}\right] \frac{d \tau}{d m^{f}}-\tau\right\}}{\Delta_{2}^{2}}$

which is necessarily negative. This result establishes the following proposition Proposition 1: A permanent increase in foreign holdings of domestic currency lowers the rate of return on the currency (1.e., raises the inflation rate) in the steady state.

All new foreign holders of the domestic currency will earn the new steady state race of return on that currency, since increased holdings In period $t$ raise $\pi_{t+1}$ to the new steady state level. During perlod $t$ In which new reserves are acquired, however, the rate of return will never fall by as much as the steady-state change and may even rise. A permanent increase in reserves held abroad will consequently increase the permanent inflation rate, though it may initially lower the inflation rate. 


\section{Multi-country Equilibrium}

Consider a world in which there are two types of countries, type I and type II. Each type of country can be characterized by a steady state inflation rate that would obtain under reserve autarky $\left(\pi_{j}^{A}, j=I\right.$, II $)$ and a rate $\bar{\pi}_{j}$ at which the long-run demand for foreign reserves is infinitely elastic. It is assumed that $\pi_{I}^{A}<\pi_{I I}^{A}$; that is, type I countries have higher inflation under autarky, and that $\bar{\pi}_{I}<\pi_{I I}^{A} ;$ that is, type I countries demand reserves at a rate of return below the autarky rate of return on type II currency. ${ }^{3}$

This section considers how the introduction of internationally held currencies will change the steady state of the world economy. It focuses first on two extreme cases, one in which reserves cannot be held in negative amounts and one in which reserves cannot be held in positive amounts. The first case corresponds to one in which loans are denominated in the borrower's currency and the second to one in which they are denominated in the lender's currency. While the model does not preclude a priori the possibility of two-way transfers of reserves, attention will focus : only on steady states in which net and gross reserve positions are identical.

\section{Nonnegative Reserves}

The following proposition can now be established:

- Proposition 2: In a steady state in which foreign reserves are held at a positive, finite level, (i) type II (low-inflation) currency will be held by type I (high-inflation) ccuntries as a reserve, and (i1) the rate of return on type II currency will fall to $\bar{\pi}_{I}$. 
If the welghts attached to future generations by each government decline geometrically--so that $\pi_{j}^{A}=\bar{\pi}_{j}, j=I$, II--then the inflation rate In type I countries does not change, while the inflation rate in type II countries will rise to $-\pi_{I}^{A}$. Thus, while under autarky $\pi_{I}^{A}=\frac{(I+n)}{\delta}, \pi_{I I}^{A}=\frac{(1+n)}{\delta I}$ (from equation $(10)$ ) when reserve holdings are allowed, $\pi_{I}^{R}=\pi_{I I}^{R}=\frac{1+n}{\delta}$; introducing reserves has raised inflation everywhere to the level in the high-inflation countries. The superscript $R$ denotes steady-state rates of return when international lending takes place. The reason is that type I countries find type II currencies attractive at their autarky inflation rates. An excess demand for these currencies will exist until the inflation rate is driven up to the level in type II countries. As type I countries accumulate reserves, the increased reserves provide an Incentive for type II countries to inflate at a higher rate, imposing an inflation tax on type I countries. Since the welfare of foreign holders of its currency, as opposed to domestic holders, does not enter the reserve Issuers' objective functions, they are less constrained to maintain low inflation rates.

The case in which $\pi_{j}>\pi_{j}^{A}$ for $j=I$ or $j=$ II is slightly more complicated. If, say, $\pi_{I}^{A}<\pi_{I}<\pi_{I I}^{A}$, then, again, type II countries will issue reserves to type I countries. In the new steady state, $\pi_{I I}^{R}=\bar{\pi}_{I}$. Again, becoming reserve currency issuers has raised inflation rates in type II countries, but not as high as the autarky inflation rate in type I countries. Type II countries will again experience strictly higher inflation rates in the new steady state.

These results suggest how introducing llabilities denominated in the borrower's currency can create more inflation in the world economy. The welfare 
implications of introducing international reserves can be analyzed in terms of our model. This paper will not attempt a thorough discussion but will make the following points:

(1) In a steady state with finfte reserves, type I (high-inflation, reserve-holding) countrles have as an additional source of government revenue an amount $\lambda \hat{\mathrm{m}}^{\star \mathrm{d}}\left[\bar{\pi}_{I}(1+n)^{-1}-1\right]$ per worker where $\hat{m}^{* d}$ denotes steady-state reserve holdings. When $w_{1}=\rho^{t+1} w_{t} i>0$, this amount equals $\lambda \mathrm{m}^{*}\left(\frac{1-\delta I}{\delta}\right)$ and when $w_{1}=0(1 \neq t-1, t)$, it equals $\lambda^{*}{ }^{*}\left(\frac{B+\delta I}{B \delta}\right)$. Taxes are lower and the rate of return on currency has not changed: The representative individual in type I countries is better off in the steady state. (Here $\delta^{I}$ denotes type I countries' value of $\delta \cdot$ )

(2) In a steady state with finite reserves, type II (low-inflation, reserve-1ssulng) countries transfer an amount $m^{f}\left[1-\pi^{*}(1+n)^{-1}\right]$ to type I countries each period. The representative individual in type II countries can be worse off in the steady state because the rate of return on his savings has declined.

(3) The older generation in the perlod in which reserves are acquired in the reserve holding countries suffers from the transition. The rate of return on their money holdings is lower than under autarky. (This result may be seen by setting $m_{t-1}^{{ }^{d}}=0$ in equation (18) and observing the effect of increasing $m_{t}^{*_{d}}$ on $\pi_{t}$ in equation (20).)

(4) The younger generation in the period in which reserves are Issued by the reserve currency country benefits from lower taxes in that perlod but experiences a lower return on savings in the subsequent period. The net effect on welfare is therefore ambiguous.

(5) The effect of the transition on the older generation in the reserve-1ssuing country is ambiguous, depending whether $\pi_{t}$ rises or falls as a consequence of lisuing reserves. 
Thus, the long-run effect of a move from reserve autarky to trade in currencles raises steady-state welfare in the reserve-holding countries but can lower steady-state welfare in the issuing countries. The effects during the transition, however, may go in the opposite direction.

One remaining question is how much currency of a typical type II country w11l be held abroad at the point where the rate of return on that country's currency equals $\bar{\pi}_{I}$. If all type II countries are Identical in all respects except relative population size each type II country will have the same per worker money stock held abroad as a reserve currency in the reserve equilibrium. The contribution of each type II country to total. international reserves will therefore be proportional to that country's population.

Nonpositive Reserves

The following proposition can also be established:

Proposition 3: In any steady state in which international borrowIng takes the form of lssuing forelgn-currency-denominated liabilities at a finite, positive level, (1) type II (low-inflation) countries will borrow from type I (high-inflation) countries, and (11) the rate of return type I currency will rise to $\bar{\pi}$ II. Consider first the case in which $\bar{\pi}_{j}=\pi_{j}^{A}, j=I$, II. If type II countries can issue liabilities denominated in type I currency, they will do so intil $\pi_{I}$ rises to $\pi_{I I}^{A}$. Thus, when positive, rather than negative, reserve holdings are precluded, international financial Integration reduces, rather than increases, inflation. The reason is that when countries lend In thelr own currency, rather than borrow by lssulng reserves denominated in their own currency, their 
governments have an incentive to reduce, rather than to increase, their Inflation rates.

The welfare effects of international financial integration when borrowing is foreign-currency denominated, both on impact and in the steady state, can be analyzed as well. The effects are substantially similar, so that issue will not be discussed here. Relaxing the Nonegativity Constraints

If no constraint is imposed on the sign of reserve issue our model admits an infinite number of solutions. While borrowing in both domestic and forefgn currency denominated assets occurs in international financial markets, the possibility of outright default may place an upper bound on the extent to which foreign currency denominated borrowing occurs. Default on such liabilities can occur without affecting the value of domestic agents'savings. As long as currency is internationally mobile, default on domestic currency held abroad could only occur if domestic households were defaulted upon as well. This ramification is likely to limit the incentive of a national government to default on its domestic currency or to destroy its value through inflation.

Introducing a Nominal Interest Rate on Borrowing

It has been assumed that money pays a zero nominal rate of return. Introducing a nonzero nominal interest rate would not affect the results, except that the inflation rate would equal the nominal rate minus the real rate of return derived here. Whatever nominal return a reserve Issuer offers its creditors ex ante, it determines the real rate of return ex post through its inflation policy. 


\section{Possible Extenstons}

This paper has developed a model for analyzing the effects of introducing reserve currencles on Inflation and welfare in the world econamy. In order to obtain concrete results the analysis has been kept very simple. We conclude with a discussion of some issues that we belleve are of considerable interest that could be analyzed in terms of the framework we develop here. Non-Bernoul11 Preferences

The assumption of the model that utility is logarithmic in consumption levels leads to savings behavior and private currency demand that is independent of the rate of return on the currency. The analysis is enormously simplified by this assumption. Alternative specifications would lead to much more complicated responses to alternative policles. In particular, the effect of expectations of future policy on the current private demand for currency would have to be incorporated into the model. Introducing non-Bernoull1 preferences would consequently introduce a much rlcher set of dynamics as well as an additional source of potential time inconsistency of optimal pol1cy. Distortionary Taxation

Our model assumes that the government has access to proportional Incame taxes as a means of raising government revenue. Since Income is exogenous in our model, such taxes are nondistortionary. If taxes do, In fact, impose an excess burden, then an additional role for selgniorage arises, as an alternative distortionary source of revenue. Differences In autarky inflation rates may then reflect differenct financing needs among countries as well as different valuations of generations by governments. The role of selgniorage as a form of optimal taxation in an open 
economy has been analyzed in a small, open economy context by Calvo (1978) and Eaton (1982), but the role of reserves in redistributing tax burdens Internationally has yet to be studied.

Default Risk

Our model does not introduce formally the possibility of outright default on foreign debt. The issue of default has by now been investigated extensively. See, for example Eaton and Gersovitz (1981a, 1981b), Sachs and Cohen (1982), or Kletzer (1982). One topic of potential interest would be to integrate analytic models of default into our paper's framework here. As suggested earlier, one important issue that such research might shed light upon is the currency of denomination of international debt.

\section{Productive Capital}

No role for productive capital exists in the model. The effects of International capital market integration on the allocation of capital has been analyzed in a nonmonetary overlapping generations model by Buiter (1981). It would be of considerable interest to investigate how the monetary phenomena considered here would interact with the international allocation of capital in the steady state. In particular, it would be interesting to determine to what extent the trading of monetary assets can substitute for trade in physical capital. Uncertainty

Our model assumes perfect certainty. Introducing uncertainty about future values of exogenous variables would provide insight into a 
number of 1ssues. For example, the effects on uncertainty on the rates of return of alternative currencies could be examined. Optimal reserve portfolios could then be characterized, which could presumably include more than one reserve held simultaneously. The role of government policy in redistributing risk between generations domestically and the role of reserves in reallocating risk internationally could be examined. Lapan and Enders (1980), Aizenman (1981), and Eaton (1982) have considered the Implications of alternative exchange rate regimes for the international allocation of risk. The implications of their analysis for reserve positions in a multicountry context have yet to be drawn out. Strategic Behavior

In our model governments make decisions taking other countries' Inflation rates and reserve positions as given. While this assumption can be justified in a competitive context in which the numbers of countries of different types arelarge, it is less appropriate in a world where some countries are unfque in their relevant characteristics. One possibility Is that strategic competition among potential reserve issuers will arise. The country which is most successful at establishing a reputation as providing a high and stable return on currency might then emerge as the sole reserve Issuer. 


\section{v. Conclusion}

The major conclustons of our analysis can be summarized in the following points:

(1) Under financlal autarky, inflation rates in different countries can be explained by their monetary authorities' attitudes toward the welfare of the younger and older generations. The problem of time consistency may yield an inflation rate that is not optimal.

(2) A government's demand for a forelgn currency as a reserve In the long run may be infinitely elastic at a rate of return that is equal to or higher than the rate of return on that country's currency. Holding a foreign currency as a reserve does not affect the steady-state Inflation rate of the reserve holder.

(3) The steady-state inflation rate of a country increases when forelgn demand for that country's currency as a reserve rises to a higher permanent level.

(4) Trade in borrower-currency-denominated assets raises the average steady-state world inflation rate, while trade in lender-currencydenominated assets has the opposite effect.

(5) Trade in assets raises steady-state lifetime welfare in reserve-holding countries but can lower it in reserve-issuing countries, although the effect on the welfare of generations allve during the transition from autarky to the new steady state may be reversed. Governments may therefore be justified in acting to prevent their currencies' use as international reserves. 


\section{FOOTNOTES}

$1 /$ Recently, Townsend (1980) has shown that the exact consumption loan specification can be generated by a much larger class of transactions technologies than that suggested by the Samuelson model and subsequent 11 terature.

2/ More generally, as Kareken and Wallace (1981) have pointed out, the multicountry model of the type we are dealing with is characterized by multiple equilibria. The paper restricts its attention to equilibria In which gross and net reserve positions are equal, and in which there is efther a nonnegativity constraint or nonpositivity constrain on reserve positions. These restrictions identify a unique steady-state equilibrium.

\section{$3 /$ Recall from the first subsection of Section I that when}

welghts on the utilities of each generation in the government's objective function in period $t$ are of the form $w_{t+i}=\rho{ }^{i} w_{t}$ for all $t$ and 1 then $\bar{\pi}_{f}=\pi_{j}^{A}$; while if $w_{1}=0,1 \neq t, t-1$, then $\bar{\pi}_{j}>\pi_{j}^{A}$. 


\section{REFERENCE}

Alzenman, Joshua, "The Use of the Balance of Payments as a Shock

Absorber in Fixed and Managed Float System," Journal of International

Economics, Vol. 11 (November 1981) pp. 479-486.

Buiter, Willem H., "Time Preference and International Lending and

Borrowing in an Overlapping--Generations Model," Journal of Political

Economy, Vol. 89 (August 1981) pp. 769-979.

Calvo, Gulllermo A., "Optimal Selgniorage from Money Creation: An

Analysis in Terms of the Optimum Balance of Payments Deficit

Problem," Journal of Monetary Economics, Vol. 4 (August 1978).

pp. 503-518.

Eaton, Jonathan and Mark Gersovitz, "Debt with Potential Repudiation:

Theoretical and Empirical Analysis", Review of Economic Studies,

Vo1. 48 (Apr11 1981a) pp. 289-310.

, "Poor Country Borrowing in Private

Financial Markets and the Repudiation Issue" Princeton Studies on

International Finance No. 47, International Finance Section,

Princeton University, (June 1981b).

, "Optimal and Time Constent Exchange Rate Management in

an Overlapping Generations Economy" Economic Growth Center

D1scussion Paper No. 413, Yale University, (July 1982).

Kareken, John and Neil Wallace, "On the Indeterminacy of Equilibrium

Exchange Rates," Quarterly Journal of Economics, Vol. 96 (May

1981) pp. 207-222. 
Kletzer, Ken, "A Model of International Lending with Default Risk" University of California, Davis, mimeo, June (Revised November 1982).

Kydland, Fynn E. and Edward C. Prescott, "Rules Rather than Discretion: The Inconsistency of Optimal Plans" Journal of Folitical Economy, Vo1. 85 (June 1977) pp. 473-491.

Lapan, Harvey E. and Walter Enders, "Random Disturbances and the Choice of Exchange Rate Regime in an Intergenerational Model", Journal of International Economics, Vo1. 10 (May 1980) pp. 263-284.

Munde11, Robert A., Monetary Theory (Pacific Palisades, Calif.: Coodyear Publishing, 1971).

Sachs, Jeffrey and David Cohen, "LDC Borrowing and Default Risk" National Bureau of Economic Research Working Paper No. 925 , (July 1982).

Samuelson, Paul A., "An Exact Consumption Loan Model of Interest with or without the Social Contrivance of Money", Journal of Political Economy, Vol. 66 (Decenber 1958) pp. 467-482.

Towns end, Robert M., "Models of Noney with Spacially Separated Agents" Models of Monetary Economics ed. by John H. Kareken and Nefl Wallace (Federal Reserve Bank of Minneapolis 1980). Triffin, Robert, Gold and the Dollar Crists, Revised Edition (New Haven: Yale University Press, 1961). 